\begin{tabular}{ccc}
\hline & International Journal of Engineering \& Technology, $7(3.30)(2018) 361-368$ \\
SPC & International Journal of Engineering \& Technology \\
Website $:$ www.sciencepubco.com/index.php/IJET & Research paper \\
\hline
\end{tabular}

\title{
Determination Acceptance of Employees, Education, Use, Maintenance, and through Termination Department of Job Satisfaction as an Intervening Personnel Variable to Improve Performance of Regional Police in Riau Islands, Indonesia
}

\author{
Chablullah Wibisono**1, Ngaliman², Susetio Cahyadi ${ }^{3}$, \\ Faculty of Economics, University of Batam, Riau Islands, Indonesia (Author *a,b,c) \\ *Corresponding author Email: chablullah.wibisono@ univbatam.ac.id, chablullahwibisono@ gmail.com
}

\begin{abstract}
Law No. 2 of 2002 on the National Police asserted that the Indonesian National Police is a tool that acts maintaining state security and public order, enforcing the law, and to provide protection, shelter, and services to the community to maintaining homeland security. People expect that the police can transform themselves and carry out what is the role and core functions well. By the Regulation. No. 22 of 2010 that the entire cycle of the Life Cycle Bin HR is the duty and responsibility of the Bureau of Human Resources assisted by some sections in charge and responsible for human resources Bin include: Section Control Personnel (Bagdalpers) is accountable for accepting, Education, and Termination; Career Development Section (Bagbinkar) accountable for the use; Care Personnel Section (Bagwatpers) is responsible for Nursing.Collecting the data in this study using a questionnaire in the form of surveys distributed to respondents amounted to 252 people, the number of respondents is only 200 questionnaires that can be processed from the 685 total number of active population of members of the police in Riau Islands Police subsequently transformed the data with models Structural Equation Model (SEM). The software used for structural analysis is AMOS 23 and Arbuckle and for descriptive analysis using SPSS 23.From the test results show that the variable acception (X1), education (X2), the use of (X3), treatment (X4), termination (X5) have an influence on the performance of $69.2 \%$, and the variable acception (X1), education (X2), use (X3), treatment (X4), termination (X5) has a $58.1 \%$ effect on job satisfaction. The conclusion of this study extends from the regression weight; it turns out that the most significant care variables $47.6 \%$. That is, the variable treatment of the most dominant influence on performance and job satisfaction
\end{abstract}

Keywords: Acception, Education, Use, Maintenance, Termination, Performance And Job Satisfaction

\section{Introduction}

Law No. 2 of 2002 on the National Police has confirmed that the National Police is an instrument of the state that plays a role in maintaining security and public order, enforcing the law, and to provide protection, shelter, and services to the community in the framework of preserving national security. The paradigm of thinking and acting of police before the Reformation tended to be placed as the Ruler tool or instrument for the interests of individual parties, has shifted and now slowly turned toward sincere and honest devotion to the interests of society, the nation, and the state. This has brought about fundamental change implications. One of those changes is the reformulation of the role of Police by Law \# 2 of 2002 on the Indonesian National Police, the which establishes that the police role as the keeper of security and public order, enforce the law, as well as protectors and Servants of the people.

According to a survey conducted by LPPM UNIBA in all regencies / Cities in Riau Islands, Riau Islands Regional Police performance seen from the "principal task force" is "medium" for the four districts/cities, the average ranged from 2:06 to 2:50, while overall is also "being" with an average of 2.15. Riau Islands Regional Police performance seen from the "police public service in general" is "medium" for the four districts/cities, the average ranged from 1.81 to $2: 22$, while as a whole is also "being" with an average of 1.92, Riau Islands Regional Police performance seen from the "police public service in particular" is also classified as "moderate" for the four districts/cities, the average ranged from 1.90 to $2: 29$, while as a whole is also."

\subsection{Formulation of the Problem}

Based on the background of the problem, then the problem can be Formulated as follows:

1. Is acceptance as a determination to police performance?

2. Is education as a determination of police performance?

3. Is use as a determination to police performance?

4. Is maintenance of the determination of police performance?

5. Is the termination of as a determination of police performance?

6. Are exceptions, education, use, maintenance and termination simultaneously as a determination to police performance?

7. Is revenue as a determination to job satisfaction?

8. Is education as a determination of job satisfaction?

9. Is used as a determination of job satisfaction?

10. Maintenance is as a determination to job satisfaction?

11. Is termination as a determination to job satisfaction? 
12. Is accepting, education, use, maintenance and termination simultaneously as a determination of job satisfaction?

13. Is performance as a determination of job satisfaction?

\subsection{Purpose of Research}

Based on the issues that have been Formulated, Formulated use of research:

1. To identify and explain the acceptance as the determination to police performance.

2. To Determine and describe education as the determinant of the performance of the police.

3. To identify and explain the use of the determination to police performance.

4. To identify and explain the maintenance as the determination of police performance.

5. To identify and explain the termination as the determination to police performance.

6. To understand and explain the acceptance, education, use, maintenance, and termination as the determination of police performance.

7. To identify and explain the acceptance as the determination to job satisfaction.

8. To know and describe the education as the determination of job satisfaction.

9. To identify and explain the use as the determination to job satisfaction.

10. To find out and explain the maintenance of as the determination of job satisfaction.

11. To identify and explain the termination as the determination of job satisfaction.

12. To identify and explain the acceptance, education, use maintenance and termination simultaneously as the determination of job satisfaction.

13. To identify and explain the performance as the determination of job satisfaction.

\section{Literature Review}

To get an understanding of the variables used in this research, it can be described as follows literature review:

\subsection{Acceptance}

"Recruitment is the act or process of an organization attempting to Obtain additional human resources for the operational purpose. Recruitment involves acquiring further human resources to serve as the institutional input ". Withdrawal of employees is the act or process of an organization's Efforts to Obtain additional employees for operational purposes. Removal involves employee human resources institution capable of functioning as an input That the withdrawal of staff included the identification and evaluation of sources, the stages in the overall process Becomes for the organization, Followed by signing the withdrawal capability, selection, placement, and orientation. Various human resource management practices that short-term thinking, and considers employees as a production tool, Ultimately in the long term detrimental to the organization itself. For example, the organization frequently fail to Prevent Acceptance (recruitment) of employees who are less competent because of kinship with the person who has a high position in the organization.

The organization Also sometimes let the admissions process (recruitment) of employees over the years are managed less competent Officials in the selection process of quality human resources. Organizations keep Reviews their recruitment process Carried out officers who are not explicitly trained in selecting and interviewing candidates. As a result, a person's decision is feasible or not an employee is taken based on limited knowledge and personal taste, not the actual competency requirements of the organization. In the concept of accepting candidates for members of the Police as Mentioned in the introduction that the commitment of the police in Realizing acceptance of its members through the principles of recognition clean, transparent, accountable and humane,

This concept is in line with the management of human resources in an organization in this era, where the role of human resources in the organization has the same meaning as necessary as a job, so the interaction between the organization and human resources Became the focus of attention of leaders at various levels of management and different organisation, both public and businesses. Therefore it is essential to adapt and socialize the values (value) that comply with the environmental demands of the organization to all elements within the organization. Shifting views on human resources as a reflection of the revitalization of the role of human resources in the activities of the organization that sees "people are no longer regarded as a cost but as assets (stock), employees are no longer focused on" competence " on the progress of Themselves, but rather on cooperation for the common good. The primary task of human resource management Often only arranged for personnel can work Effectively. Attention is too centered on the interests of the organization of work tends to be accompanied waiver of Reviews their right to be treated humanely.

\subsection{Education}

The purpose of education and training is actually as a means of supporting the objectives of human resources management higher. The highest use of human resource management is creating a cadre for the survival of the organization. An organization is considered successful if it can provide a force of leaders that is greater than the needs of the organization at the time before the need arises. An organization is lucky when you get a good leader. But in the end, the natural law states that every leader must give up the leadership seat someday. Every good leader will go. When good leaders leave, the organization must be Able to prepare his successor with other leaders who are as good or even better. Even organization should be Able to provide a stock of leader more than required. Instead, the organization is less fortunate if you get the less useful leader. This leader initially was great leaders in the past but is not to the needs and demands of today's modern era.

The concept of education is an old paradigm that has been felt for years. Indeed, some false model that have Contributed to human treatment is wrong in the organization. Some issues continue to repeat and still not finished. Because the concept of education, especially the education members of the police has been currently set and change the paradigm, as the long-held model must change.Police professionalism is indeed needed to be evaluated, Because The police have not been Able to work professionally, in terms of improving the ability to handle police work, and that can be done in a way closer policeman to the world the education as a resource to enhance Reviews their capabilities in order to improve the science and technology. Professional is a job that is based on specific skills, acquired through the education implemented a particular According to the code of conduct, no salary system, no system of recruitment and beneficial to humanity. Thus Spake the higher of police education, they are expected to be more professional. Training for the police is essential Because It Gives knowledge and knowledge to Affect and shape attitudes and provide skills.

There are at least two serious obstacles confronting professionalism of the police is weak in technical mastery of specific to policing and weak managerial, both of them which are an essential prerequisite in the operation of a modern police force According to the demands of today's modern society. The education level Affect greatly managerial capability, Including sharpness and sensitivity to analyze problems and make decisions. Changing a strategy and education policy must go through public 
hearings / internal, so it does not seem the euphoria of leadership (who is leading has the authority to change).

\subsection{Use}

The use or placement is the final process of selection acceptance and equipping of education (1). In general, the function the use of the entire personnel of the police in maintaining order and providing services to citizens who need it, in other words, the concept of the method is as apparatus protectors, servant and helper of society and law enforcement in maintaining internal security in the Midst of society from threats and acts of crimes that disturb the safety and mentally and materially detriment. Therefore providing guidance to all personnel of the police is an integral part that integral to Obtain qualified corps, referring to the views Expressed by Sullivan (1985: 18) that to be a 'good cop, at least the required five things items, namely well recruited, well educated, well trained, well equipped, and well paid.

\subsection{Maintenance}

Every police officer is supposed to gain attention from the support that includes licensing and Furlough, salary increases Periodically, awards, Determining the level or class of defects even to matters of marriage and divorce, considering that the police officers are Servants of the state are in daily to maintain order and peace amongst the people. However, in practice still found concerning the maintenance of personnel such as the unclear criteria and parameters of the reward system to police officers who excel. So far the awards tend to range to be only given to Reviews those in charge of operational functions, particularly subject to the task of detectives, more specifically anti-terror. How parameters to Obtain rewards for personnel who served in the mission of management, or staff such as, Taud, Yanma, IT Div, Dokken, and others.

\subsection{Termination}

Termination of the police department is the final activity of an administrative process of a police officer of the Republic of Indonesia in its implementation implemented an According to procedures and regulations. According to Law 20 of 1952, that may be retired are old, invalid, Unable to work in any position due to illness, rejuvenated, and retooling. Some experts suggested that the retirement of the personnel is closely related to the results Achieved on the list of personal skills assessment, so it was not at my age (1).Retirement is on the company's desire dismissal of personnel, law, or desire Reviews their personnel. The company's desire to retire its staff because of low productivity as a result of old age, physical disability, accident in carrying out the work, and so on.

Service of documentation fees related to the termination of departments can be implemented a quickly intervening and precisely, if supported by a complete and correct the data, short bureaucracy, and a short time. For the documents, the service can be implemented a quickly intervening and precisely, it is Necessary to published guidelines for the implementation of the maintenance service termination letters to members of the national police agency.

\subsection{Performance}

Definition of performance is the result of the quality and quantity of work accomplished by an employee in performing duties According to to the responsibility given to him. Meanwhile, The performance is the result of work that can be Achieved by a person or group of people in an organization, According to Reviews their authorities and responsibilities of each, in an effort to Achieve the goals of the organization in question legally, do not violate the law and in accordance with moral and ethical.Performance is the appearance of the work of both the quantity and quality of personnel in an organization. Performance can be an individual or group performance of staff. Armstrong and Baron in (Wibowo, 2007: 2) stated that the performance is about doing the work and results of the work. Performance is the result of work that has a healthy relationship with the organization's strategic objectives, customer satisfaction and Contributes to the economy.

Produced by performance is the outcome of a particular job function or activity for a specific period. The performance is the result of work Achieved in executing the tasks assigned to them based on skills, experience, seriousness and time. Public expectations to police performance are already Often Discussed in public discourse, the which is in essence the public wants the police to Realize the main task well, the which is based on morality, professionalism as civilian police, and have a unique closeness to the people. Public expectations to police performance are already Often Discussed in public discourse, the which is in essence the public wants the police to Realize the main task well, the which is based on morality, professionalism as civilian police, and have a unique closeness to the people. Hope it was not excessive. Therefore, every member of the police Also had to Consider Several things:

1. Know himself, means to know and understand, and appreciate exactly who he was (as a member of the civilian police), understand and appreciate Reviews their duties and how to do a good job, as well as follow what the necessity and prohibitions.

2. Personal integrity, it means being honest, fair and trustworthy in doing the task.

3. Self-control that means it can postpone gratification and ACTED proportionately and is not emotional.

4. Commitment and consistency, it means to have a strong determination to be good police as protectors and Servants of the people.

5. Confidence, the which means that in carrying out duties not being Hesitant, firm but restrained and Werner polite.

6. Flexible means not rigid in the act.

\subsection{Job Satisfaction}

Satisfaction is a barometer of success of an organization or institution in serving and helping organisasi Achieve service levels. If a person is satisfied with the treatment of the issue of services, then people will continue to the make an assessment of the organization or institution, the which in turn will impact the success of an organization or institution. Job satisfaction in general always concerns a person's attitude to the job. According to (2) job satisfaction is the emotional attitude of fun and loves her job. Job satisfaction of personnel must be created as well as possible to morale, dedication, passion, and discipline of staff Increased. This attitude is reflected by the confidence, training, and job performance. Enjoy job satisfaction in the job, off the job, and a combination of inside and outside of work. Job satisfaction in the post is a job satisfaction be enjoyed in a career by gaining the praise of the work, placement, treatment, equipment, and the atmosphere of a good working environment. Personnel who prefer to enjoy job satisfaction in a job will prioritize work rather than remuneration even if the payment is essential.

Robbins and Judge (2009: 113) defined job satisfaction as positive feelings about work as the result of the evaluation of the working code. Similarly, Noe, etc. all (2006: 436) defined job satisfaction as a pleasant feeling as the result of the perception that the work meets the values important work. Furthermore, Kinicki and Kreitner (2005: 125) defined job satisfaction as an attitude or emotional response to various aspects of a person's job. This definition Gives the meaning of that job satisfaction is not a single concept. Relatively moreover one can be satisfied with one aspect of his work and made dissatisfied with one or various elements. In 
a very Similar view, Nelson and Quick (2006: 120) stated that job satisfaction is a positive emotional state and enjoyable as the result of the assessment of jobs or work experience person. As well as in the police institution, job satisfaction is a common problem that Often Occurs and is experienced by each member in each work unit, work unit, or individual sections in the police institution. In essence, the job satisfaction of members of the police is intimately connected directly or indirectly with the motivation of members' work, fidelity (loyalty) members and their peace of the members in action, and does not rule out the possibility of job satisfaction is also associated with the level of discipline members of the police in carrying out the task.

In general, people found Reviews their salary every month is a crucial factor to Achieve job satisfaction of members of the Police. This is due to get a salary, members can carry out their daily lives and can even provide for his family. But in reality, the pay received is not always a significant factor for Achieving the job satisfaction of every member of the Police. In fact, in addition to Salaries, the Government Also added Reviews their performance benefits to each member every month to support and Enhance motivation and job satisfaction of members of the police, but in reality there are many members of the police that were not satisfied with the work even though the Salaries and benefits of performance supported it.

\subsection{Framework}

Based on Background and theoretical base that has been Mentioned are the variable acceptance, education, use, maintenance, and termination. Reviews These five variables are more Clearly the framework of this research can be illustrated by the following diagram.

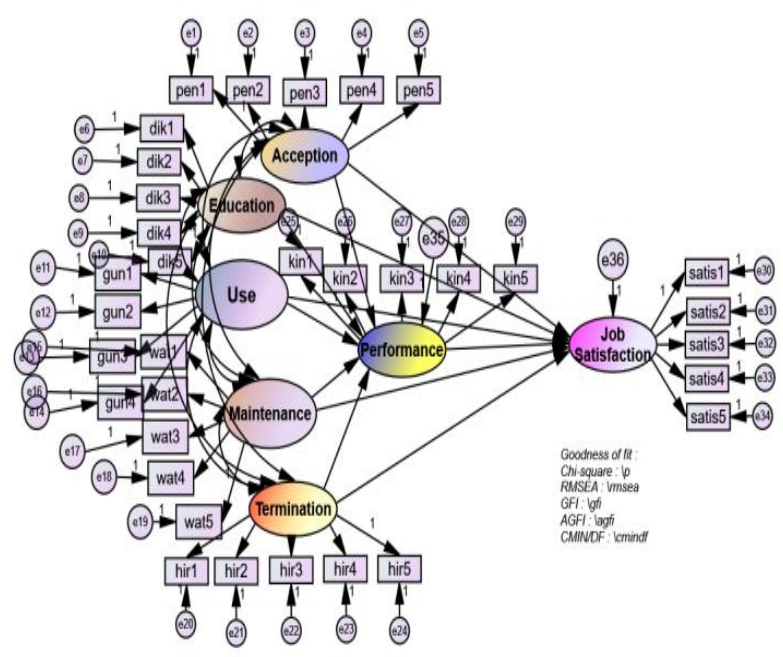

DETERMINATION ACCEPTION, EDUCATION, USE, MAINTENANCE, AND TERMINATION OF DEPARTMENT THROUGH JOB SATISFACTION AS AN INTERVENING VARIABLE TO IMPROVE PERSONNEL PERFORMANCE OF REGIONAL POLICE IN RIAU ISLANDS

Figure 1: Model of Framework

\subsection{Hypothesis}

From the theoretical basis and the framework of the above ideas can be Formulated the following theories:

1. Acceptance as the determination of police performance.

2. Education as a determination to police performance.

3. The use of as the determination of police performance.

4. Maintenance as the determination of police performance.

5. Termination as the determination of police performance.

6. Acceptance, Education Use, Maintenance and Termination simultaneously as the determination of police performance.

7. Acceptance as the determination to job satisfaction.
8. Education as a determination to job satisfaction

9. Use as the determination to job satisfaction.

10. Maintenance as the determination of job satisfaction.

11. Termination as the determination of job satisfaction.

12. Acceptance, Education, Use, Maintenance and Termination simultaneously as the determination of job satisfaction.

13. Performance as the determination of job satisfaction.

\section{Methodology}

The method used in the research include population and sample, sampling techniques, techniques of data collection and the data analysis techniques.

1. Population. In this research are members of the Regional Police in Riau Islands roommates are still active.

2. Samples. According to Solimun (2004) provide general guidelines for the number of samples when using the SEM is as much as 5-10 times from overall indicators of latent variables. With some symbols with 46 items, then the minimum number of samples to be taken is as much as $46 \mathrm{x}$ $5=230$ samples. However, eligible to be used as much as 215 samples. Sampling is done by using proportional accidental sampling. Mechanical comparable did so that examples can represent respondents,

3. Data Collection Techniques in this research was done by:

a. Distributing questionnaires. The spread of this questionnaire was made to all members that are Active of Regional Police Riau Islands.

b. Documentation, the which is record things that are important and useful in the preparation of this paper include the study of literature and regulations of Police.

4. Data Analysis Techniques,

Data analysis techniques using Structural Equation Model (SEM) assisted by AMOS 23.0 program. The principle of this analysis is an integrated approach to the factor analysis, channel analysis and structural models (Arief, 2003: 1). The research of variables acceptance, educación, use, Maintenance and terminación, performance and job satisfaction conducted and intended to confirm the hypothesis through the empirical data models. Hypothetical models are shown in the framework. Meanwhile, the observed Data Obtained from 215 respondents sample. Each respondent was asked to answer questionnaires roommates had been tested for validity and reliability. Data results of questionnaires subsequently processed by Amos program for Windows version 23.0 for examining the effect of by SEM. SEM Analysis of was preceded by an evaluation of data normality and CFA. Analysis of the data normality to Determine Whether or not a normal distribution of the data for each indicator, while confirmatory factor analysis (CFA) was used to test unidimensionality of dimensions that describe the latent variables in the models.

Based on analysis of the data normality as there are no indicators that have a cr for skewness above $\pm 3: 00$. This means that the distribution of the data for all signs is standard regarding skewness. Judging from kurtosis, no indicator has a value above cr> 3:00.This means the views of kurtosis can be said that the spread of the data for all indicators is standard spread (not sharp). Based on the results of confirmatory factor analysis to indicators of all of variables, either in the form of a diagram or in tabular way, it is known that the Standardized Regression Weight $(\lambda)$ All indicators of higher than 0:50 and coefficient CR bigger than 2:00 and the indicator probability value less than 0:05 (***). Tus it can be said regarding the CFA, that all the indicators are strong for latent variables defined. Thus, all the indicators can be included in the SEM analysis. 


\section{Result and Finding}

\subsection{Research Object}
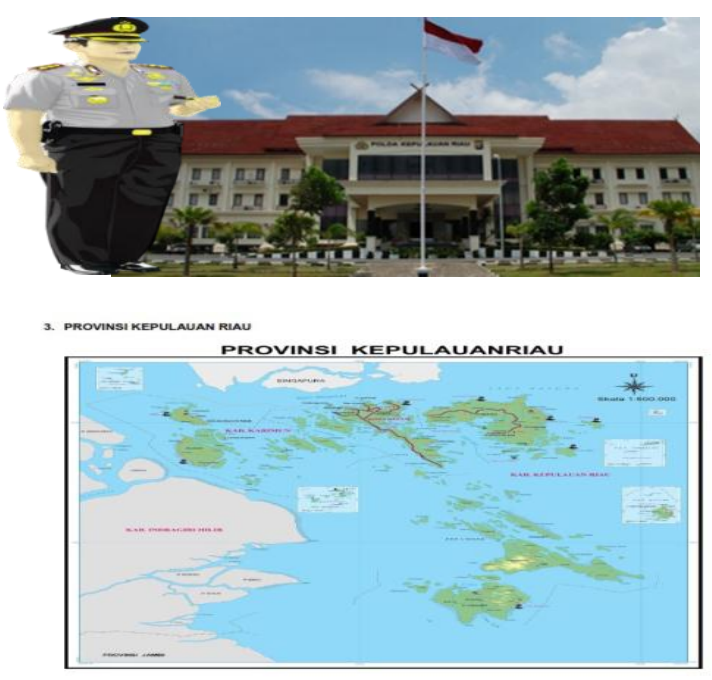

\subsection{Effect Analysis by SEM}

Data score of respondents' answers to any further processed with statistical indicators Full Model Structural Equation Modeling (SEM) using AMOS software for windows version 23.0 was Obtained display like the image processing results Structural Equation Modeling (SEM) following

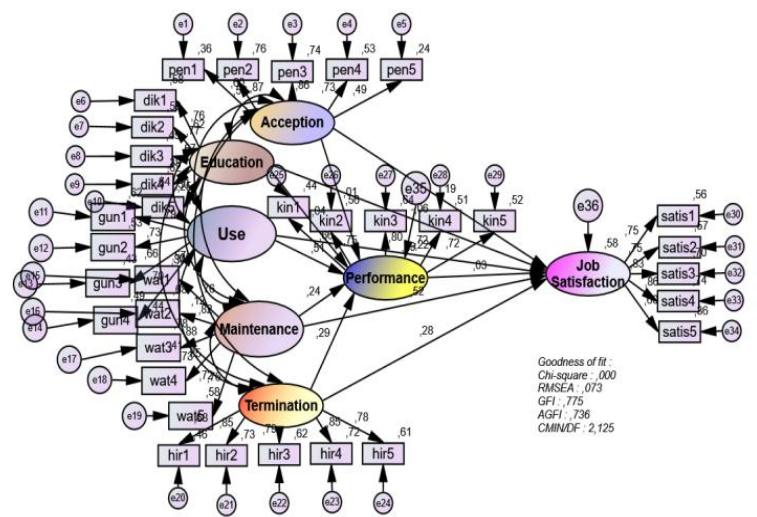

DETERMINATION ACCEPTION, EDUCATION, USE, MAINTENANCE, AND TERMINATION OF DEPARTMENT THROUGH JOB SATISFACTION AS AN INTERVENING VARIABLE TO IMPROVE PERSONNEL PERFORMANCE OF REGIONAL POUICE IN RIAU ISLANDS

\section{Figure 2: Full Mode}

Testing structural equation modeling is done by using the regression coefficient $(\gamma)$ For the Acceptance $(\mathrm{PEN}=\mathrm{X} 1)$, Education $(\mathrm{DIK}=\mathrm{X} 2)$, Use $(\mathrm{GUN}=\mathrm{X} 3)$, Maintenance $(\mathrm{WAT}=$ $\mathrm{X} 4)$, Termination $(\mathrm{HIR}=\mathrm{X} 6)$ variables to Performance $(\mathrm{KIN}=\mathrm{Y})$ and Job Satisfaction (SATIS $=\mathrm{Z}$ ) through the table output from the submenu view / set. Based on the calculation of regression coefficient (regression weight) can be presented as the output table is presented in Table.

Table.1.Regression Weights: (Group number 1 - Default model)

\begin{tabular}{|l|l|l|r|r|r|r|l|}
\hline & & & $\begin{array}{r}\text { estimat } \\
\text { e }\end{array}$ & SE & CR & P & Label \\
\hline PER & $<--$ & ACC &, 004 &, &, 066 &, & par_1 \\
F & - & & & 05 & & 947 & \\
\hline PER & $<--$ & $\begin{array}{l}\text { Communiti } \\
\text { es }\end{array}$ &, 053 & 5 &, 447 &, & par_2 \\
& & & & 11 & & 655 & \\
\hline
\end{tabular}

\begin{tabular}{|c|c|c|c|c|c|c|c|}
\hline $\begin{array}{l}\text { PER } \\
\text { F }\end{array}$ & $\begin{array}{l}<- \\
-\end{array}$ & TERM &, 225 & $\begin{array}{r}08 \\
4\end{array}$ & 2,680 & 007 & par_4 \\
\hline $\begin{array}{l}\text { PER } \\
\text { F }\end{array}$ & $\begin{array}{l}-- \\
-\end{array}$ & USE &, 511 & $\begin{array}{r}11 \\
8 \\
\end{array}$ & 4.313 & $* * *$ & par_8 \\
\hline $\begin{array}{l}\text { PER } \\
\text { F }\end{array}$ & $\begin{array}{l}-- \\
-\end{array}$ & MAIN &, 171 & $\begin{array}{r}07 \\
0\end{array}$ & 2,451 & $\begin{array}{r}.01 \\
4\end{array}$ & par_9 \\
\hline $\begin{array}{l}\text { FAC } \\
\text { T }\end{array}$ & $\begin{array}{l}<-- \\
-\end{array}$ & PERF &, 040 & $\begin{array}{r}16 \\
3 \\
\end{array}$ &, 244 & 807 & par_3 \\
\hline $\begin{array}{l}\text { FAC } \\
\text { T }\end{array}$ & $\begin{array}{l}-- \\
-\end{array}$ & $\overline{A C C}$ &, 173 & $\begin{array}{r}07 \\
6 \\
\end{array}$ & 2,280 & 023 & par_5 \\
\hline $\begin{array}{l}\text { FAC } \\
\text { T }\end{array}$ & $<-$ & TERM &, 275 & $\begin{array}{r}11 \\
4 \\
\end{array}$ & 2,406 & $\begin{array}{r}.01 \\
6\end{array}$ & par_6 \\
\hline $\begin{array}{l}\text { FAC } \\
\text { T }\end{array}$ & $\begin{array}{l}-- \\
-\end{array}$ & $\begin{array}{l}\text { Communiti } \\
\text { es }\end{array}$ &,- 100 & $\begin{array}{r}15 \\
6\end{array}$ &,- 642 & 521 & par_7 \\
\hline $\begin{array}{l}\text { FAC } \\
\text { T }\end{array}$ & $\begin{array}{l}<- \\
-\end{array}$ & USE &,- 286 & $\begin{array}{r}17 \\
5\end{array}$ & 1.641 & 101 & $\begin{array}{l}\text { par_1 } \\
0\end{array}$ \\
\hline $\begin{array}{l}\text { FAC } \\
\text { T }\end{array}$ & $\begin{array}{l}<-- \\
-\end{array}$ & MAIN &, 476 & $\begin{array}{r}10 \\
4\end{array}$ & 4.589 & **** & $\begin{array}{l}\text { par_1 } \\
1\end{array}$ \\
\hline
\end{tabular}

Table 2: Standardized Regression Weights: (Group number 1 - Default model)

\begin{tabular}{|l|l|l|r|}
\hline & & & Estimate \\
\hline PERF & $<--$ & ACC &, 005 \\
\hline PERF & $<--$ & Communities &, 040 \\
\hline PERF & $<---$ & TERM &, 288 \\
\hline PERF & $<---$ & USE &, 505 \\
\hline PERF & $<--$ & MAIN &, 240 \\
\hline FACT & $<--$ & PERF &, 031 \\
\hline FACT & $<---$ & ACC &, 193 \\
\hline FACT & $<---$ & TERM &, 275 \\
\hline FACT & $<--$ & Communities &,- 059 \\
\hline FACT & $<--$ & USE &,- 222 \\
\hline FACT & $<--$ & MAIN &, 523 \\
\hline
\end{tabular}

Observing the standardized estimate forthe variables Acceptance $(\mathrm{PEN}=\mathrm{X} 1)$, Education $(\mathrm{DIK}=\mathrm{X} 2)$, Use $(\mathrm{GUN}=\mathrm{X} 3)$, Maintenance $($ WAT $=X 4)$, Termination $(\mathrm{HIR}=\mathrm{X} 5)$, toPerformance $(\mathrm{KIN}=\mathrm{Y})$ and Job Satisfaction $($ SATISFIED $=\mathrm{Z})$ then it can be be made the structural equation model as follows:

$\mathrm{Y}=\gamma_{\mathrm{y} 1 . \times 1} \mathrm{X} 1+\xi_{1}=0,005 \mathrm{X} 1+\xi_{1}$

$\mathrm{Y}=\gamma_{\mathrm{y} 1 . \mathrm{x} 2} \mathrm{X} 2+\xi_{1}=0,040 \mathrm{X} 2+\xi_{1}$

$\mathrm{Y}=\gamma_{\mathrm{y} 1 . \times 3} \mathrm{X} 3+\xi_{1}=0,505 \mathrm{X} 3+\xi_{1}$

$\mathrm{Y}=\gamma_{\mathrm{y} 1 . \times 4} \mathrm{X} 4+\xi_{1}=0,240 \mathrm{X} 4+\xi_{1}$

$\mathrm{Y}=\gamma_{\mathrm{y} 1 . \times 5} \mathrm{X} 5+\xi_{1}=0,288 \mathrm{X} 5+\xi_{1}$

$\mathrm{Z}=\gamma_{\mathrm{zx} 1} \mathrm{X} 1+\xi_{2} \quad=0,193 \mathrm{X} 1+\xi_{2}$

$\mathrm{Z}=\gamma_{\mathrm{zx} 2} \mathrm{X} 2+\xi_{2} \quad=-0,059 \mathrm{X} 2+\xi_{2}$

$\mathrm{Z}=\gamma_{\mathrm{ZX} 3} \mathrm{X} 3+\xi_{2}=-0,222 \mathrm{X} 3+\xi_{2}$

$\mathrm{Z}=\gamma_{\mathrm{zx} 4} \mathrm{X} 4+\xi_{2} \quad=0,523 \mathrm{X} 4+\xi_{2}$

$\mathrm{Z}=\gamma_{\mathrm{zx} 5} \mathrm{X} 5+\xi_{2} \quad=0,275 \mathrm{X} 5+\xi_{2}$

$\mathrm{Z}=\beta_{\mathrm{zy} 1} \mathrm{Y}+\xi_{2} \quad=0,031 \mathrm{Y}+\xi_{2}$

\subsection{Determination Analysis}

Analysis of measurement models with determination is used to Determine the variable contribution. Therefore, used Square Multiple Correlation in the following table.

Table.2.Squared Multiple Correlations: (Group number 1 - Default model)

\begin{tabular}{|l|r|r|r|}
\hline & & & Estimate \\
\hline PERF & & &, 692 \\
\hline FACT & & &, 581 \\
\hline
\end{tabular}

Square Multiple Correlation of performance variables (KIN) amounted to 0,692 . Tus it can be stated that the change of 
performance is affected by the acceptance (X1), education (X2), use (X3), maintenance (X4), termination (X5) amounted to $69.2 \%$. Value Square Multiple Correlation to job satisfaction (Satisfied) of 0581. Tus it can be stated that the change of job satisfaction is affected by the acceptance (X1), education (X2), use (X3), maintenance (X4), termination (X5) of $58.1 \%$. Variables of Acceptance (X1), education (X2), use (X3), maintenance (X4), termination (X5) has the effect of $69.2 \%$. On performance. And the acceptance (X1), education (X2), use (X3), maintenance (X4), termination (X5) has the effect of $58.1 \%$. To job satisfaction Viewed from variable regression weight maintenance, it turns variable regression weight for the most significant support (0476). That is the maintenance of variable most dominant effect on performance and job satisfaction.

\subsection{Goodness of Fit}

Referring to the Value Goodness of Fit as shown in the figure above, it can be prepared the following table.

Table.3 Goodness of Fit Evaluation

\begin{tabular}{|c|c|c|c|}
\hline $\begin{array}{l}\text { Goodness Of Fit } \\
\text { Index }\end{array}$ & $\begin{array}{l}\text { Cut-Of } \\
\text { Value }\end{array}$ & $\begin{array}{c}\text { Results } \\
\text { Model }\end{array}$ & Information \\
\hline Chi-Square $\left(\chi^{2}\right)$ & $\begin{array}{l}\text { Expected } \\
\text { Small } \\
\end{array}$ & $0.00 *)$ & Good \\
\hline $\begin{array}{c}\text { Relatitive Chi-Square } \\
\left(\chi^{2} / \mathrm{Df}\right)\end{array}$ & $\leq 3.00$ & $2.125 *)$ & Good \\
\hline Probability & $>0.05$ & 0,000 & Not Good \\
\hline RMSEA & $\leq 0.08$ & $0.073 *)$ & Good \\
\hline GFI & $\geq 0.90$ & $0,775+)$ & Marginal \\
\hline AGFI & $\geq 0.90$ & $0,736+)$ & Marginal \\
\hline TLI & $\geq 0.95$ & $0,852+)$ & Marginal \\
\hline CFI & $>0.95$ & $0,867+)$ & Marginal \\
\hline
\end{tabular}

+) Marginal

Observing the cut-of-value and goodness of fit of the model results in Table 3 above shows only three criteria were fulfilled and four marginal and one less good than the eight criteria used. Criteria met is Chi-square $\left(\chi^{2}\right)$ Relative Chi-square $\left(\chi^{2} / \mathrm{Df}\right)$ and RMSEA, the which is marginal FGI, AGFI, TLI, and CFI. Because there are three criteria are fulfilled and minimal four of the eight standards required, then the above models can be Expressed as a good model of (Solimun, 2004: 71).

\subsection{Discussion}

\begin{tabular}{|c|c|c|c|c|}
\hline $\begin{array}{c}\text { Variable } \\
\text { Determination }\end{array}$ & $\begin{array}{c}\text { estimate } \\
(\lambda \mathbf{i})> \\
0.50\end{array}$ & $\begin{array}{l}\text { CR } \\
(t)> \\
2.00\end{array}$ & $\begin{array}{c}P \\
<0.05\end{array}$ & Discussion \\
\hline $\begin{array}{l}\text { Acceptance of } \\
\text { Performance }\end{array}$ &, 005 & ,066 & ,947 & $\begin{array}{l}\text { Variable } \\
\text { Determination } \\
\text { Acceptance } \\
\text { performance, to } \\
\text { positive effect was } \\
\text { not significant, the } \\
\text { findings are less by } \\
\text { the theory that the } \\
\text { Committee did not } \\
\text { accept deposits } \\
\text { Prospective cadets, } \\
\text { there is no } \\
\text { intervention from } \\
\text { both outside and } \\
\text { within the National } \\
\text { Police. The process } \\
\text { and the result of } \\
\text { selection can be } \\
\text { justified vertically } \\
\text { and horizontally; the } \\
\text { selection process is } \\
\text { supported by the } \\
\text { Information } \\
\text { Technology so that }\end{array}$ \\
\hline
\end{tabular}

\begin{tabular}{|c|c|c|c|c|}
\hline & & & & $\begin{array}{l}\text { it can be seen } \\
\text { directly by the } \\
\text { participants }\end{array}$ \\
\hline $\begin{array}{ll}\text { Education } & \text { on } \\
\text { Performance } & \end{array}$ & ,040 & ,447 & ,655 & 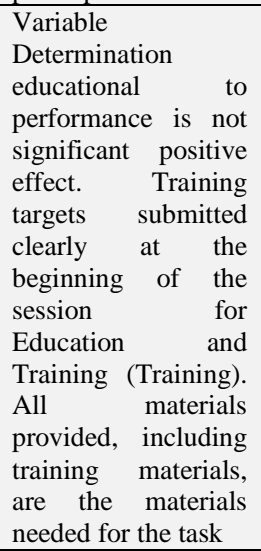 \\
\hline $\begin{array}{l}\text { Use of the } \\
\text { Performance }\end{array}$ &, 505 & 4.313 & $* * *$ & $\begin{array}{l}\text { Variable } \\
\text { Determination, The } \\
\text { use of Performance, } \\
\text { is the significant } \\
\text { positive effect. As } \\
\text { members of the } \\
\text { police are required } \\
\text { to display the } \\
\text { optimal performance } \\
\text { in carrying out basic } \\
\text { tasks, both as for } \\
\text { law enforcement } \\
\text { officials, protectors, } \\
\text { waiter and helper } \\
\text { society and in } \\
\text { maintaining internal } \\
\text { security. Posture } \\
\text { personnel } \\
\text { Indonesian National } \\
\text { Police (INP) is a } \\
\text { professional, moral } \\
\text { and modern is a } \\
\text { prerequisite that } \\
\text { must be realized that } \\
\text { the Police were able } \\
\text { to meet the } \\
\text { expectations of all } \\
\text { stake hold }\end{array}$ \\
\hline $\begin{array}{l}\text { Performance eye } \\
\text { care }\end{array}$ &, 240 & 2,451 & .014 & $\begin{array}{l}\text { variable } \\
\text { Determination Eye } \\
\text { Care is a significant } \\
\text { positive impact } \\
\text { performance. } \\
\text { Services for the } \\
\text { submission of } \\
\text { license and leave, } \\
\text { salary increases } \\
\text { periodically, satisfy } \\
\text { members of the } \\
\text { Police }\end{array}$ \\
\hline $\begin{array}{l}\text { Termination of } \\
\text { Performance }\end{array}$ &, 288 & 2,680 &, 007 & 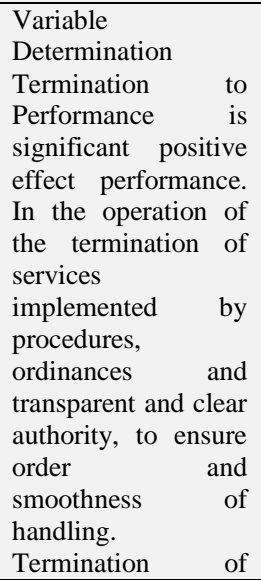 \\
\hline
\end{tabular}




\begin{tabular}{|c|c|c|c|c|}
\hline & & & & $\begin{array}{l}\text { office administration } \\
\text { held well-supported } \\
\text { with complete data, } \\
\text { right, the latest as } \\
\text { well as the } \\
\text { completion of a } \\
\text { rapid, precise and } \\
\text { implemented } \\
\text { according to the } \\
\text { correct procedure }\end{array}$ \\
\hline $\begin{array}{l}\text { performance to } \\
\text { the satisfaction }\end{array}$ &, 031 &, 244 &, 807 & $\begin{array}{l}\text { Determination } \\
\text { Performance to } \\
\text { Satisfaction is the } \\
\text { significant positive } \\
\text { effect. Increasing } \\
\text { faith and devotion } \\
\text { member through } \\
\text { Spiritual Guidance } \\
\text { Tatalaksan } \\
\text { (binrohtal), to make } \\
\text { a good moral. } \\
\text { Maximizing the } \\
\text { performance of good } \\
\text { to excellent service } \\
\text { to the community }\end{array}$ \\
\hline $\begin{array}{l}\text { Acceptance } \\
\text { Satisfaction }\end{array}$ &, 193 & 2,280 &, 023 & $\begin{array}{l}\text { Determination } \\
\text { Acceptance } \\
\text { Satisfaction of } \\
\text { reception significant } \\
\text { positive effect. Are } \\
\text { fair and do not } \\
\text { discriminate against } \\
\text { the selection of all } \\
\text { participants, the } \\
\text { timing of the } \\
\text { participants to break. } \\
\text { Motivate the } \\
\text { participants of } \\
\text { candidates receiving } \\
\text { Youth Police } \\
\text { Academy (Police } \\
\text { Academy) who do } \\
\text { not meet }\end{array}$ \\
\hline $\begin{array}{ll}\text { Education } & \text { on } \\
\text { Satisfaction } & \end{array}$ &,- 059 &,- 642 &, 521 & $\begin{array}{l}\text { Determination } \\
\text { Education on } \\
\text { Satisfaction the } \\
\text { significant negative } \\
\text { effect. Not all } \\
\text { materials provided } \\
\text { include ingredients } \\
\text { for Education and } \\
\text { Training (Training) } \\
\text { is the materials } \\
\text { needed for the task. } \\
\text { Not enough } \\
\text { opportunity to } \\
\text { practice the skills } \\
\text { taught during } \\
\text { training, and yet } \\
\text { satisfying members } \\
\text { of the Indonesian } \\
\text { National Police } \\
\text { (INP) }\end{array}$ \\
\hline $\begin{array}{l}\text { The use of the } \\
\text { Satisfaction }\end{array}$ &,- 222 & $\begin{array}{c}- \\
1.641\end{array}$ &, 101 & $\begin{array}{l}\text { Determination The } \\
\text { use of negative } \\
\text { satisfaction to } \\
\text { insignificant. } \\
\text { embodiment posture } \\
\text { of police personnel } \\
\text { was professional, } \\
\text { moral and modern } \\
\text { than me mechanism } \\
\text { of formation of } \\
\text { police personnel not } \\
\text { constitute one of the } \\
\text { pillars determinants } \\
\text { must be capable of } \\
\text { optimally }\end{array}$ \\
\hline
\end{tabular}

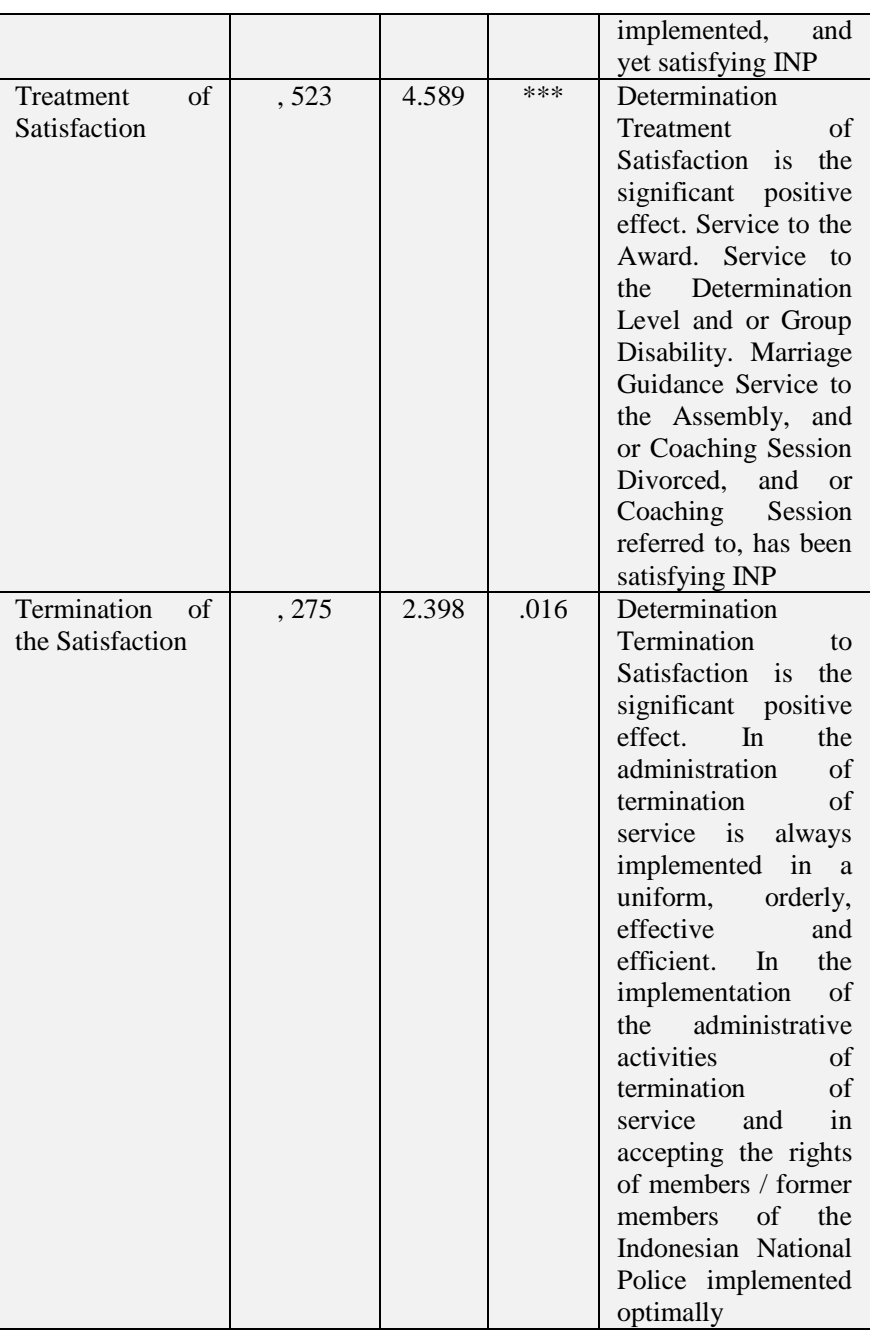

\section{Conclusion and Suggestion}

\subsection{Conclusion}

Thus, based on the description above can be Expressed there is a significant positive effect pattern of Acceptance (X1) on the Performance $(\mathrm{Y})$ of 0005 . There is a pattern of significant positive effect Education (X2) on the Performance (Y) amounted to 0,040. There is a significant positive influence pattern Use (X3) on the Performance $(\mathrm{Y})$ of 0505 . There is a significant positive effect pattern Maintenance (X4) on the Performance (Y) of 0240. There is a significant positive effect pattern Termination (X5) on the Performance (Y) of 0288. And there is a significant positive effect pattern Performance (Y) to Job Satisfaction (Z) of 0,031 . This means that if acceptance (X1), education (X2), use (X3), maintenance (X4), and termination (X5), increases, so performance $(\mathrm{Y})$ will Increase. If the performance $(\mathrm{Y})$ increases, job satisfaction (Z) Also Increased. In contrast, if acceptance (X1), education (X2), use (X3), maintenance (X4), and termination (X5), then decreases performance (Y) will reduce. If the performance (Y) down then job satisfaction (Z) Also declined. That is, the hypothesis:

1) Acceptance as a determination of the performance verified, but it was not significant.

2) Education as a determination of the performance verified, but it was not significant.

3) Use as a determination of the performance verified, but not significant.

4) Maintenance of a determination of the performance verified

5) Termination as a determination of the performance verified. 
6) Acceptance, education, use maintenance and termination simultaneously as the determination of performance verified.

7) Acceptance as the determination to job satisfaction verified.

8) Education as the determination to job satisfaction of is not verified.

9) Use as the determination to job satisfaction of is not verified.

10) Maintenance as the determination of job satisfaction verified.

11) Termination as the determination of job satisfaction verified.

12) Acceptance, use, maintenance, and termination as the determination to job satisfaction verified.

13) Performance as the determination to job satisfaction verified, but it was not significant.

\subsection{Suggestion}

1. To The Police Regional Police Riau islands to be Able to use this structural equation model in analyzing problems of acceptance, education, use, maintenance and termination related to the performance and job satisfaction.

2. Due to the variable acceptance but did not Significantly Affect the implementation of the recruitment and selection of candidates for members of the police, not to accept deposits and there should be no intervention both from outside and from inside. Recruitment is transparent to empower internal and external monitoring, and the selection process should be supported by information technology so that it can be transparently Viewed directly by the of participants.

3. The education variable is not significant, so education and training goals should be clear, to reinforce learning, with the materials needed in the task as well as provide an opportunity for members to practice the skills taught in training, in order do not cause counterproductive from the science gets.

From performance to job satisfaction is not the significant need for the improved element of faith and devotion binrohtal members through activities, to maximize the performance of excellent service to the community. Police Realize the unique programs and adjust to the local culture.

\section{References}

[1] Manulang M., (2013). Fundamentals of Management, Ciptapustaka Media Pioneer, Bandung.

[2] Hasibuan, M., (2007), Human Resource Management, Earth Literacy, Indonesia Jakarta

[3] AAAAAAAAAAAAA

[4] Byars, LL, and LW, Rue, (2005), Human Resources Management, Mc Graw-Hill, New York

[5] Casio, Wayne F. (1992). Performance Assessment Program. Publisher Gramedia Pustaka Utama, Jakarta

[6] Duwi Priyatno, (2010). Understand Data Statistical Analysis With SPSS, Publisher Mediakom East Krasak Yogyakarta

[7] Duwi Priatno, (2010), How to Quick Study Data Analysis with SPSS 20, Publisher Andi Yogyakarta

[8] Ferdinand, Augusty (2002.Structural Equation Modeling in Management Studies, Faculty of Economics, Diponegoro University in Semarang

[9] Kotler, P., (2000). Marketing Management, The Millenium Edition, New Jersey: Prentice Hall International, Inc.

[10] Kinicki, Angelo and R. Kreitner, (2005), Organizational Behavior Key Concepts Skills And Best Practice, Mc Graw-Hill, New York

[11] Kottler and Keller (2009). Marketing Management, Thirteenth Edition, publisher Indonesia

[12] Kuswadi, (2004). How to Measure Employee Satisfaction. Publisher Alex Mediakomputindo, Jakarta

[13] Lupiyodi R., (2001).Manajemen Marketing Service (Theory and Practice), Issue I, Salemba Four, Jakarta

[14] Luthans, F., (2005), Organizational Behavior, Mc Graw-Hill Book Co-Singapore, Singapore

[15] Lupiyodi Creep, (2011). Marketing Management Services, Issue 2. Publisher Salemba Four, Jakarta

[16] Mowen, JC, and M. Minor, (1998). Consumer Behavior, 5th Ed Upper Saddle River, NJ: Prentice Hall, Inc.
[17] Mangkunagara, AA.Prabu, (2008). Corporate Human Resource Management, Youth Rosdakarya

[18] Nasution, (2008). Research Methods (Scientific Research) Tenth Matter. Publisher CV Earth Literacy, Jakarta

[19] Nelson, DL, and JC, Quick, (2006), Foundations of Behavior Organizational Realities and Challenges, Thompson SouthWestern, United States of America

[20] Noe, RA, et al., (2006), Human Resources Management, Mc GrawHill, New York

[21] Noermijati and Ristri, (2010). Efforts to Increase Job Satisfaction Members of the Police Through Fulfillment And Compensation Management Applications UB's Journal

[22] Oliver, Richard L., (1999). WHENCE Consumer Loyalty, Journal of Marketing, Vol 63 (particular issue) pp. 33-44

[23] Rucky S A. 2001. Performance Management System. Jakarta Publisher Gramedia Pustaka Utama

[24] Robbin SP and Judge TA, (2007). Organizational Behavior (Translation; Organizational Behavior). Publisher Salemba Four Jakarta

[25] Robbins, SP, and TA, Judge, (2009), Organizational Behavior, Pearson Prentice Hall, United States of America, New York

[26] Suharsimi, Arikunto, (1998), Research Procedure A Practice Approach, Publisher Jakarta Rineka Reserved.

[27] Siagian, (1999). Human Resource Management. Publisher Jakarta, Earth Literacy, Jakarta

[28] Santoso, Singgih, 2002, Multivariate Statistics: Exercise Book SPSS, PT. Elex Media Komputindo, Jakarta

[29] Sarwono, Jonathan, 2012. Thesis Research Methods Quantitative Approach, Publisher PT Elex Mediakomputindo, Jakarta

[30] Siagian, SP. (2003). Human Resource Management, Publisher Jakarta Earth Literacy

[31] Simamora, Henry (2004). Human Resource Management, Yogyakarta, STIE YKPN

[32] Solimun, (2004). Public Lecture Material Preparation and Use of SEM through AMOS Operations In Research, Study Program Master of Management Undiknas Denpasar

[33] Sugiyono, (2008). Qualitative and Quantitative Research Methods R \& D, Mold Fourth. Publisher Alfabeta, Bandung

[34] Sunyoto Danang, (2011). Research Methodology To Eknomomi, Publisher CAPS, Yogyakarta

[35] Tse \& Wilton, (1988). Models of Consumer Satisfaction Formation: An Extension, Journal of Marketing Research, pp.204-212

[36] Tjiptono F., 2000. Management Services, 2nd Edition, Andi, Yogyakarta,

[37] Tjiptono Fandy, (2004) .service Quality Satisfaction. Andi Yogya

[38] Tjiptono Fandy (2011). Service, Quality \& Satisfaction, Issue 3. Publisher CV Andi Offset, Yogyakarta

[39] Wibowo, Arief (2003).Pengantar Structural Equation Analysis (Structural Equation Modeling $=$ SEM), Module Airlangga University, Surabaya

[40] Wahid Sulaiman, (2004). Regression Analysis Using SPSS (Case Examples and Solutions), Publisher Andi Yogyakarta

[41] Wibowo, General. (2012). Practical application of SPSS In the study, Publisher Gava Media, Yogyakarta 